\title{
Immunoregulatory Dysfunctions in Type I Diabetes: Natural and Antibody-Dependent Cellular Cytotoxic Activities
}

\author{
MADHAVAN P. N. NAIR, ${ }^{1,2,4}$ ERIC W. LEWIS, ${ }^{3}$ and STANLEY A. SCHWARTZ ${ }^{1,2}$
}

Accepted: May 5, 1986

Peripheral blood lymphocytes from 13 patients with established insulin-dependent diabetes mellitus (IDDM) and 2 prediabetic patients were examined for natural killer (NK) and antibody-dependent cellular cytotoxic activities (ADCC), lectin-dependent cellular cytotoxicity (LDCC), interferon- and interleukin-2-induced cytotoxicity, and concanavalin A-induced suppressor-cell activities in comparison with age-matched normal controls. IDDM patients demonstrated normal levels of NK and ADCC activities against $\mathrm{K} 562$ and antibody-coated SB target cells, respectively, compared to controls. IDDM patients showed normal levels of LDCC activity. Notable deviations from control values were, however, observed with diabetic lymphocytes in the following systems. Interferon- and interleukin-2-induced NK activities were significantly higher with IDDM lymphocytes than with control cells. IDDM lymphocytes precultured with concanavalin A demonstrated lower NK and ADCC activities than control cells and manifested decreased suppressor effects on the NK activity of normal allogeneic lymphocytes. Lymphocytes from one of two prediabetic patients showed increased $\mathrm{NK}, \mathrm{ADCC}$, and LDCC activities in comparison to controls. The increased interferon- and interleukin-2-induced enhancement of NK activity and reduced suppressor activity of lymphocytes from IDDM patients may be involved in the pathogenesis of the disease.

KEY WORDS: Insulin-dependent diabetes mellitus; prediabetes; immunoregulation; natural killer cells; interferon; interleukin-2.

Department of Pediatrics, The University of Michigan, Ann Arbor, Michigan 48109 .

2Department of Epidemiology, The University of Michigan, Ann Arbor, Michigan 48109.

3Department of Internal Medicine, The University of Michigan, Ann Arbor, Michigan 48109.

To whom correspondence should be addressed at The University of Michigan, 109 South Observatory, Room 1029 SPH-I, Ann Arbor, Michigan 48109.

\section{INTRODUCTION}

Recent evidence has suggested a role for autoimmune mechanisms in the pathogenesis of insulindependent diabetes mellitus (IDDM). Support for this premise derives from several observations made in diabetic patients. Lymphocytic infiltration of pancreatic islets has been described in patients with IDDM (1). The presence of specific islet-cell antibodies has been noted generally during the early stages of disease $(2,4)$; these antibodies may exhibit complement-dependent cytotoxicity against islet cells (3). Increased numbers of functional $T$ cells have been observed in the peripheral blood of IDDM patients (6) and some of these cells were "activated" T cells (5). Specific destruction of islet cells by immune lymphocytes from diabetic patients can occur in vitro (7). Finally, patients with IDDM can manifest delayed- and/or immediate-type hypersensitivity to insulin and pancreatic extracts $(8,9)$.

Recent studies on natural killer (NK) and antibody-dependent cellular cytotoxic (ADCC) effector cells have examined their role in immunologic surveillance against tumors and in the regulation of various immune reactions (10-12). The significance of $\mathrm{NK}$ and $\mathrm{ADCC}$ reactions and the mechanisms that control these functions have not previously been examined in patients with type I diabetes. The present studies were designed to investigate the NK and ADCC activities of lymphocytes from patients with IDDM and prediabetes in comparison with normals. Further, the immunoregulatory effects of diabetic lymphocytes precultured with and without concanavalin A (Con A) on the NK activities of lymphocytes from normal allogeneic donors were also examined. These studies demonstrate that pa- 
tients with type I diabetes have normal ranges of $\mathrm{NK}$ and ADCC activities against tumor target cells. However, compared to healthy controls, diabetic lymphocytes showed decreased Con A-inducible suppressor-cell activity on the NK functions of normal allogeneic lymphocytes.

\section{MATERIALS AND METHODS}

\section{Patients}

Thirteen white IDDM patients, six males and seven females, ranging in age from 17 to 37 years, with a disease duration of 1.5 to 23 years (mean, 13.9 years), were investigated. All patients were receiving insulin at the time of study. Twelve of the 13 patients were seronegative for cytoplasmic isletcell antibodies (ICA) as determined by immunofluorescence using fresh-frozen human blood group $O$ pancreas as described (2). Two white prediabetic patients, a male aged 27 years and a female aged 25 years, were also examined. The diagnosis of prediabetes was based on strongly ICA-positive sera and a normal insulin response to IVGTT in the male and an abnormal OGTT with normal fasting and postprandial blood glucose in the female.

\section{Controls}

A group of 15 age-matched, healthy, white volunteers of both sexes with no history of autoimmune disease, allergy, or diabetes was investigated for comparison.

\section{Isolation of Lymphocytes}

Peripheral blood mononuclear cells (PBMC) were isolated from heparinized $(20 \mathrm{U} / \mathrm{ml})$ venous blood using a modified method of Boyum (13). Blood was diluted with an equal volume of normal saline and centrifuged at $400 \mathrm{~g}$ for $30 \mathrm{~min}$ at $18^{\circ} \mathrm{C}$. The mononuclear-cell band was harvested, washed three times with saline, and resuspended in RPMI 1640 medium, containing $25 \mathrm{mM}$ Hepes buffer supplemented with $10 \%$ heat-inactivated fetal calf serum (FCS) (GIBCO, Grand Island, NY), $80 \mu \mathrm{g} / \mathrm{ml}$ gentamicin (Schering Corp., Kenilworth, NJ), and $300 \mu \mathrm{g}$ fresh glutamine/ml (complete medium).

\section{Depletion of Adherent Cells}

PBMC were suspended in RPMI 1640 with $10 \%$ FCS and depleted of adherent cells by passage through a 7-ml column of Sephadex G-10 beads (Pharmacia Fine Chemicals, Piscataway, NJ), equilibrated in the same medium. After $45 \mathrm{~min}$ of incubation at $37^{\circ} \mathrm{C}$, nonadherent peripheral blood lymphocytes (PBL) were eluted with 1 bed vol of medium at $37^{\circ} \mathrm{C}$. Cell recovery was $>70 \%$ of the total input and monocyte contamination as indicated by nonspecific esterase staining was $<2 \%$.

\section{Preparation of Target Cells}

The human erythroleukemia cell line, K562, was used as targets for NK cells in a 4 -hr ${ }^{51} \mathrm{Cr}$ release assay. For the ADCC assay, we chose as targets an antibody-coated human B-cell leukemia line (SB) because of its resistance to NK activity. Target cells passaged for $48 \mathrm{hr}$ were washed twice with CM. To $0.8-\mathrm{ml}$ aliquots of $\mathrm{CM}$ containing $5 \times 10^{6}$ tumor cells, $200 \mu \mathrm{Ci}$ of ${ }^{51} \mathrm{Cr}$ as sodium chromate (New England Nuclear, Boston, MA) was added. The cells were incubated at $37^{\circ} \mathrm{C}$ for $1 \mathrm{hr}$ in a humidified atmosphere of $5 \% \mathrm{CO}_{2}$ in air with intermittent shaking. Following incubation, the cells were washed three times with $\mathrm{CM}$ and resuspended to a concentration of $1 \times 10^{5}$ cells $/ \mathrm{ml}$.

\section{Assay for NK Activity}

NK activity was measured in a direct ${ }^{51} \mathrm{Cr}$ release assay as previously described (14). A fixed number of viable effector cells in $\mathrm{CM}$ was added to triplicate cultures of ${ }^{51} \mathrm{Cr}$-labeled targets in V-bottom microtitration plates (CoStar, Cambridge, MA). After centrifugation at $40 \mathrm{~g}$ for $2 \mathrm{~min}$, they were incubated at $37^{\circ} \mathrm{C}$ in a humidified atmosphere of $5 \% \mathrm{CO}_{2}$ in air for $4 \mathrm{hr}$. At the end of incubation the plates were centrifuged at $400 \mathrm{~g}$ for $10 \mathrm{~min}$ and $100-\mu \mathrm{l}$ aliquots were removed from each well, transferred to glass tubes, and read in a Packard Model 593 gamma counter. Percentage cytotoxicity was calculated as follows:

$$
\begin{aligned}
& \% \text { cytotoxicity }= \\
& \frac{\text { experimental release }- \text { spontaneous release }}{\text { total release }- \text { spontaneous release }} \times 100,
\end{aligned}
$$

where spontaneous release represents counts released from control wells containing $1 \times 10^{4}$ target 
cells, and total release represents counts obtained from an aliquot of $1 \times 10^{4}$ target cells. Cytotoxicity was also expressed as lytic units (LU) per $10^{7}$ effector cells, defined as the number of effector cells needed to yield $30 \%$ cytotoxicity of $1 \times 10^{4}$ target cells. LU were calculated by linear regression analysis from a cytotoxicity curve using four different effector-to-target (E:T) cell ratios for each test as described by Kadish et al. (15).

\section{Assay for ADCC Activity}

ADCC activity was determined as previously described (14). Briefly, $50 \mu \mathrm{l}$ of varying concentrations of effector cells was added to $50 \mu \mathrm{l}$ of $\mathrm{CM}$ containing ${ }^{51} \mathrm{Cr}$-labeled SB target cells and $100 \mu \mathrm{l}$ of a $2 \times 10^{-4}$ dilution of rabbit anti-SB antiserum previously found to yield maximum ADCC. Percentage cytotoxicity was calculated as described above for NK activity with the following exceptions. Spontaneous release represents counts released in control wells containing effector cells, ${ }^{51} \mathrm{Cr}$-labeled SB target cells, and medium without anti-SB antibody, and total release represents counts obtained in an aliquot of $1 \times 10^{4}$ labeled target cells.

\section{Lectin-Dependent Cell-Mediated Cytotoxicity (LDCC) Assay}

The LDCC assay was carried out similarly to the NK assay except that NK-resistant SB cells were used as targets (16). Briefly, different numbers of target and effector cells were added to V-bottom microtitration plates, followed by phytohemagglutinin-P (PHA; Difco Laboratories, Detroit, MI) at concentrations of $1,2.5$, and $5 \mu \mathrm{g} / \mathrm{ml}$ to a final volume of $0.2 \mathrm{ml}$. The plates were incubated for $4 \mathrm{hr}$ at $37^{\circ} \mathrm{C}$ in a humidified $5 \% \mathrm{CO}_{2}$ in air incubator. Percentage LDCC activity was calculated as described for NK activity and was compared with cytotoxicity observed with control cultures containing effector and target cells in the absence of PHA. Percentage cytotoxicity was calculated as follows:

$$
\begin{aligned}
& \% \text { cytotoxicity }= \\
& \frac{\text { experimental release }- \text { spontaneous release }}{\text { total release }- \text { spontaneous release }} \times 100,
\end{aligned}
$$

where spontaneous release represents counts released from control wells containing $1 \times 10^{4}$ target cells alone plus lectin, and total release represents counts obtained in an aliquot of $1 \times 10^{4}$ target cells.

\section{Interferon}

Recombinant interferon-alpha (IFN) (specific act, $\sim 1 \times 10^{8} \mathrm{U} / \mathrm{mg}$ protein) was a gift from Schering Corp., Bloomfield, NJ. IFN was diluted in RPMI 1640 and stored at $-70^{\circ} \mathrm{C}$ before use. The maximum NK augmenting dose was $250 \mathrm{U} / \mathrm{ml}$ as previously determined.

\section{Interleukin-2 (IL2)}

Commercially available IL2 (Electro-Nucleonics Labs, Inc., Silver Spring, MD) was diluted in RPMI 1640 and stored at $-70^{\circ} \mathrm{C}$ before use. IL2 was purified from human peripheral blood leukocytes by several chromatographic steps and is devoid of any lectin or IFN. A final concentration of $64 \mathrm{U} / \mathrm{ml}$, the maximal NK augmenting dose as previously determined, was used.

\section{In Vitro Generation of Suppressor Cells with Con $A$}

Total PBL were suspended in CM at a concentration of $4 \times 10^{6}$ cells $/ \mathrm{ml}$, to which Con $\mathrm{A}$ at a concentration of $30 \mu \mathrm{g} / \mathrm{ml}$ was added. A duplicate set of cultures received $C M$ without Con $A$ as a control. All cultures were incubated in a humidified environment of $5 \% \mathrm{CO}_{2}$ in air at $37^{\circ} \mathrm{C}$ for $48 \mathrm{hr}$. Cells were washed four times with saline and resuspended in $\mathrm{CM}$ as described (17). Cell viability as determined by trypan blue dye exclusion was not affected by concentrations of $\leq 30 \mu \mathrm{g}$ Con $\mathrm{A} / \mathrm{ml}$ and was found to be $>70 \%$. The viability was comparable with that of control cultures. Estimation of nonspecific esterase-positive cells was approximately $10.5 \%$ in control cultures and about $6.0 \%$ in Con A-treated cultures. The percentage of phagocytic cells, as identified by ingestion of latex particles, was approximately $9 \%$ in control cultures and about $4.5 \%$ in Con A-treated cultures.

\section{Assay of Suppressor-Cell Activity}

In coculture experiments to measure suppressorcell activity, PBL precultured with or without Con A were added to a mixture of effector and prelabeled target cells. The observed cytotoxicity demonstrated by the cell mixture was compared to the sum 
of cytotoxicities shown by precultured PBL and effector cells when tested alone. In these mixing experiments the E:T cell ratio and suppressor-toeffector (S:E) cell ratio were maintained at 50:1 and $1: 1$, respectively. All plates were treated as described for the cytotoxicity assay. Percentage suppression was calculated as detailed elsewhere (17) or, briefly, as follows:

$$
\% \text { suppression }=\frac{\begin{array}{l}
\text { predicted cytotoxicity } \\
\text { observed cytotoxicity }
\end{array}}{\text { predicted cytotoxicity }} \times 100 \text {, }
$$

where predicted cytotoxicity is calculated as the sum of the individual cytotoxicities of effector cells plus precultured PBL, and observed cytotoxicity is the cytotoxicity demonstrated by the mixture of effector and precultured PBL. Results are expressed as mean values \pm SE. The statistical significance of differences in mean values was determined using a single-tail Student $t$-test formula.

\section{RESULTS}

\section{NK and ADCC Activities of Lymphocytes from IDDM Patients}

Figure 1A shows the NK activity of normal, diabetic, and prediabetic lymphocytes, at different E:T cell ratios. A total of 12 IDDM and 2 prediabetic patients was compared with 12 normal controls at each E:T cell ratio. Diabetic patients manifested considerable variation in their NK activity at all E:T cell ratios. At a 50:1 E:T cell ratio, diabetic patients showed cytotoxicity ranging from 3 to $69 \%$, with a mean of $39 \%$, compared to a mean of $51 \%$ for normals $(P<0.2)$. At a $25: 1 \mathrm{E}: \mathrm{T}$ cell ratio; diabetic patients demonstrated a mean of $29 \%$ NK activity, compared to $37 \%$ cytotoxicity manifested by normals $(P<0.2)$. At 10:1 and 5:1 E:T cell ratios, diabetic patients demonstrated a mean of 20 and $13 \%$ NK activity, respectively, compared to a mean of $19(P<0.2)$ and $12 \%(P<0.2)$, by normals. One of two prediabetic patients demonstrated increased NK activities of $69,60,44$, and $25 \%$ at $50: 1,25: 1$, 10:1, and 5:1 ET cell ratios, respectively. Figure 1B shows that 10 diabetic patients demonstrated a mean of $24,17,12$, and $9 \%$ ADCC activity, compared to $39(P<0.2), 29(P<0.2), 23(P<0.2)$, and $10 \%(P<0.1)$ shown by 10 normals at 50:1, 25:1, 10:1, and 5:1 E:T cell ratios, respectively. One of two prediabetic patients also showed increased
ADCC activity compared to controls at all E:T cell ratios. In summary, only 2 of 11 IDDM patients manifested markedly lower levels of NK activity ( 3 and $12 \%$ killing), while 2 other IDDM patients demonstrated decreased levels of ADCC activity (1 and 5\% killing) at 50:1 E:T cell ratios. A similar pattern of reduced NK and ADCC activities was observed at other E:T cell ratios for these two patients. These data demonstrate that NK and ADCC activities of lymphocytes from IDDM patients are comparable to those of normals.

\section{Lectin-Dependent Cellular Cytotoxicity of IDDM Lymphocytes}

Since the majority of IDDM lymphocytes demonstrated normal levels of NK and ADCC activities, we investigated whether they could be further activated by lectin. Data presented in Table I demonstrate that normal lymphocytes produced significantly increased cytotoxicity, against nonsensitive NK targets, SB cells, at all PHA concentrations, compared to negligible cytotoxicity in the absence of PHA. Diabetic lymphocytes exhibited a cytotoxicity of $2 \%$ without PHA, which was signifcantly enhanced by the addition of PHA. It is interesting to note that one prediabetic patient produced $21 \%$ spontaneous cytotoxicity against the usually insensitive SB target cells, which was further enhanced with varying concentrations of PHA. The second prediabetic patient showed enhancement of cytotoxicity with PHA comparable to that of diabetic lymphocytes. These data suggest that the percentage enhancement of cytotoxicity by PHA was comparable in diabetics and controls, although a greater than normal enhancement of LDCC was demonstrated in one of two prediabetic patients.

\section{In Vitro Effect of Glucose and Insulin on the NK Activity of Normal Lymphocytes}

To investigate whether the poor glycemic control often seen at diagnosis of IDDM patients could also influence the cytotoxic activities of their lymphocytes, PBL from normal donors preincubated for 24 hr with varying concentrations of glucose were examined for NK activity. Data presented in Table II demonstrate that a range of glucose concentrations did not show any effect on the NK activity of normal lymphocytes. We also examined whether insulin could modulate the cytotoxic functions of normal lymphocytes (Table III). These results dem- 

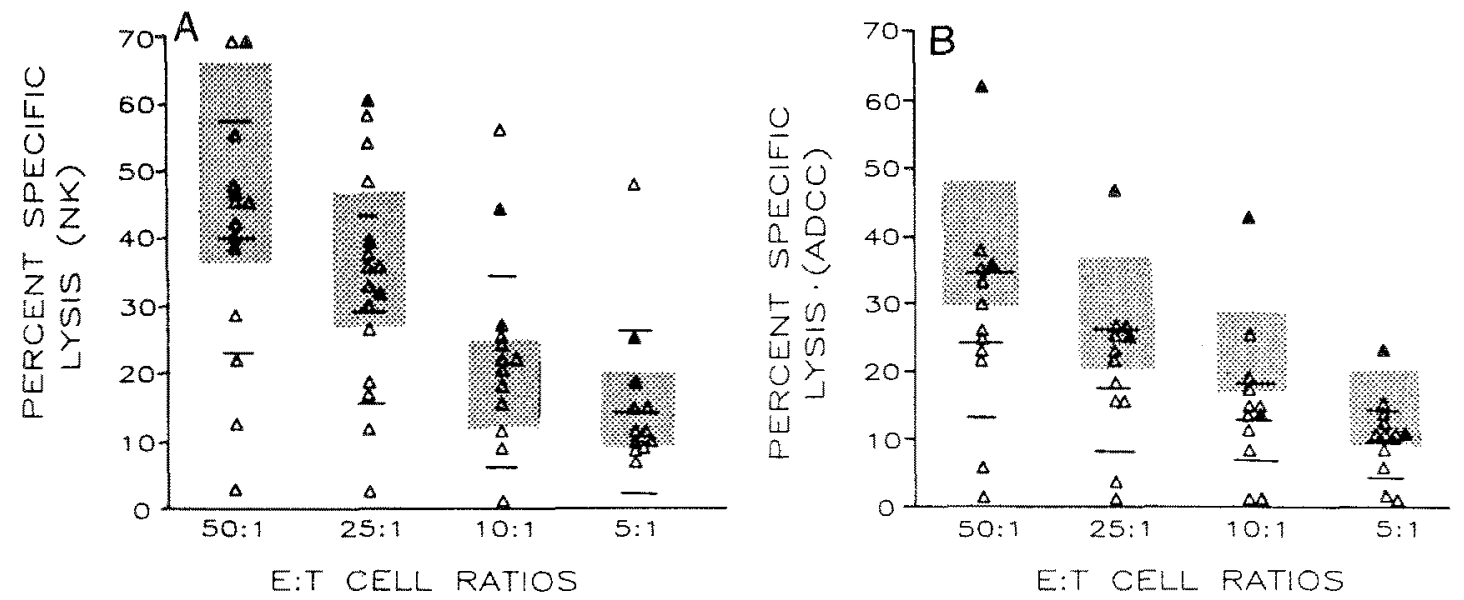

Fig. 1. (A) NK activity of lymphocytes from patients with IDDM and prediabetes. Effector cells were depleted of phagocytic cells and $\mathrm{K} 562$ targets were labeled with ${ }^{51} \mathrm{Cr}$ as detailed in Materials and Methods. $\triangle$, IDDM patients; $\boldsymbol{\Delta}$, prediabetic patients. The shaded area is the range of control cells and horizontal lines define the mean \pm SD of the patient values. (B) ADCC activity of lymphocytes from patients with IDDM and prediabetes. Effector cells were depleted of phagocytic cells and antibody-coated SB target cells were labeled with ${ }^{51} \mathrm{Cr}$ as detailed in Materials and Methods. $\triangle$, IDDM patients; $\Lambda$, prediabetic patients. The shaded area is the range of control cells and horizontal lines define the mean $\pm \mathrm{SD}$ of the patient values.

onstrate that lymphocytes precultured with varying concentrations of pork insulin showed a moderate enhancement of their NK activity compared to control lymphocytes.

\section{Effect of IFN and IL2 on NK Activity of IDDM Lymphocytes}

PBL from IDDM patients and normal donors were examined for the ability of IFN or IL2 to enhance cytotoxicity against K562 tumor target cells. Data presented in Fig. 2, representing the mean \pm SD of four separate experiments performed in triplicate, demonstrate that PBL from IDDM patients precultured with IFN or IL2 showed significantly more enhancement of their cytotoxicity, compared to lower IFN- or IL2-induced enhancement of the NK activity of normal lymphocytes. Viability of IDDM lymphocytes precultured with IFN or IL2 was $>85 \%$, comparable with that of similarly treated control cultures as assessed by trypan blue dye exclusion.

Suppression of NK Activity of Fresh Lymphocytes by Lymphocytes Precultured with Con $A$

We studied the effect of preculturing total PBMC with and without Con A to induce suppressor cells.

Table I. Effect of Lectin on Cellular Cytotoxicity of Lymphocytes ${ }^{a}$

\begin{tabular}{l}
$\begin{array}{l}\text { Lymphocyte } \\
\text { source }\end{array}$ \\
\cline { 2 - 6 }
\end{tabular}


Table II. Effect of Glucose on NK Activity of Normal Lymphocytes in vitro ${ }^{a}$

\begin{tabular}{cc}
\hline $\begin{array}{c}\text { Glucose concentration } \\
(\mathrm{mg} / \mathrm{dl})\end{array}$ & $\begin{array}{c}\text { NK reactivity }^{b} \\
\text { (lytic units/10 }^{7} \text { effector cells) }\end{array}$ \\
\hline 0 & $66.0^{c}$ \\
500 & 67.4 \\
250 & 66.7 \\
100 & 60.9 \\
50 & 67.2 \\
10 & 56.0
\end{tabular}

${ }^{a}$ Effector PBL $\left(2 \times 10^{6} / \mathrm{ml}\right)$ depleted of adherent cells were precultured with varying concentrations of glucose for $24 \mathrm{hr}$, washed, and tested for NK activity as described in Materials and Methods.

${ }^{b}$ Cytotoxicity was calculated as lytic units per $10^{7}$ effector cells as described in Materials and Methods.

${ }^{c}$ Values represent the mean of triplicate determinations of a representative experiment. Three other experiments produced similar results.

Data presented in Fig. 3 show that normal PBMC precultured with $30 \mu \mathrm{g}$ Con $\mathrm{A} / \mathrm{ml}$ displayed significantly lower levels of NK activity than manifested by PBMC precultured in medium alone. In contrast, PBMC from diabetic patients precultured with Con A did not exhibit any significant inhibition of cytotoxicity compared to patients' cells in the absence of Con $A$. The failure of Con A to reduce the cytotoxicity of patients' PBMC to levels comparable to those of healthy donors suggests a potential defect in the generation of Con A-inducible suppressor cells in IDDM. Results presented in Table IV demonstrate that normal donor lymphocytes precultured with Con A suppressed the cytotoxicity of allogeneic normal lymphocytes. Lymphocytes from three of five diabetic patients precultured with Con A showed diminished suppression of the NK activity of fresh normal, allogeneic lymphocytes. PBL from both prediabetic patients precultured with Con A, however, showed marked inhibition of the NK activity of normal lymphocytes.

\section{DISCUSSION}

Because of the role of autoimmune mechanisms in the pathogenesis of IDDM, analysis of the immune status of diabetic patients may be of significance in understanding the disease process. Recent evidence suggests that $\mathrm{NK}$ and $\mathrm{ADCC}$ reactions are important in the regulation of various immunological reactions, in addition to their proposed role in immune surveillance against tumors and virus-infected cells (9-11). Several studies on the immunologic activities of lymphocytes from IDDM patients have yielded conflicting results (17-19). Huang and MacLaren (7) showed an enhanced cytoadherence and cytotoxicity of IDDM lymphocytes to insulinoma cells, and Pozzilli et al (21) and Sensi et al. (6) demonstrated an increased number of lowaffinity sheep erythrocyte rosette-forming cells in IDDM. In an extensive analysis using a xenogenic system Charles et al. (22) demonstrated that PBL from IDDM patients showed cell-mediated cytotoxicity against rat islet-cell targets. Harold et al. (23) and Chandy et al. (24) have reported a decreased level of circulating Leu $7^{+}$cells in newly diagnosed type I disease. Kohler et al. (25) observed that $46 \%$ of newly diagnosed patients' sera supported ADCC activity against pancreatic islet cells. A marked reduction of $\mathrm{T} 3, \mathrm{~T} 4, \mathrm{~T} 8$, and $\mathrm{M} 1$ antigen expression on the lymphocytes of newly diagnosed IDDM patients compared to patients with long-standing disease has been reported (26).

The results of the experiments described herein demonstrate that, in general, lymphocytes from IDDM patients express NK and ADCC activities comparable to those of matched normal controls (Figs. 1A and B). The wide variation of $\mathrm{NK}$ and ADCC activities observed in diabetic patients may be associated with heterogeneity of disease including duration, genetic profile, insulin response, etc. It is interesting to note that one of two patients with prediabetes who were seropositive for ICA demonstrated increased NK and ADCC activities, sug gesting that dysfunction of immune surveillance mechanisms may occur during the period preceding clinical onset of the disease.

It has been previously demonstrated that lymphocyte cytotoxicity can be activated by lectin. The exact function of lectin activation is not presently understood, but it has been suggested that it may act directly on cytotoxic cells by rearranging receptors for recognition sites on target cells or providing sufficient signals to trigger subsequent lytic events $(27,28)$. In this report the percentage enhancement of LDCC in diabetic patients is similar to that in normals (Table I). However, the increased basal cytotoxicity of lymphocytes from one prediabetic patient against SB targets, which are not sensitive to NK activity, could be a manifestation of the prodrome of IDDM. A more comprehensive assessment of immune function should be undertaken in diabetes.

Recently it has been demonstrated that insulin may be associated with immunostimulation. Helderman and Raskin (29) found a comparable 
Table III. In vitro Effect of Insulin on the NK Activity of Normal T Lymphocytes ${ }^{a}$

\begin{tabular}{|c|c|c|c|c|}
\hline \multirow{2}{*}{$\begin{array}{l}\text { Insulin } \\
\text { concentration } \\
(\mu \mathrm{U} / \mathrm{ml})\end{array}$} & \multicolumn{4}{|c|}{ Cytotoxicity $^{b}$ experiment $\mathrm{No}$. } \\
\hline & 1 & 2 & 3 & 4 \\
\hline 0 & $19.2^{c}$ & 25.6 & 39.4 & 31.0 \\
\hline 100 & $29.8(55.2)^{d}$ & $34.4(34.3)$ & $53.8(36.5)$ & $57.0(83.8)$ \\
\hline 25 & $29.2(52.0)$ & $36.5(42.5)$ & $53.2(34.0)$ & $55.5(79.0)$ \\
\hline 10 & $26.1(35.9)$ & $34.6(35.1)$ & $51.2(29.9)$ & $53.9(73.8)$ \\
\hline 1 & $35.4(84.3)$ & $36.3(41.7)$ & $51.0(29.4)$ & $\mathrm{ND}^{e}$ \\
\hline 0.1 & $27.5(43.2)$ & $33.5(30.8)$ & $50.4(27.9)$ & ND \\
\hline
\end{tabular}

$2 \times 10^{6} \mathrm{~T}$ cells $/ \mathrm{ml}$ were precultured with pork insulin for $24 \mathrm{hr}$, washed, and tested for NK activity at a $20: 1 \mathrm{E}: \mathrm{T}$ cell ratio. The viability of treated lymphocytes was $78 \%$, comparable to that of control cells.

${ }^{b}$ Cytotoxicity was calculated as described in Materials and Methods.

Values represent the mean percentage cytotoxicity of triplicate determinations.

Values in parantheses represent the percentage enhancement of cytotoxicity compared to control cells.

ENot done.

number of insulin receptors on PHA-activated T cells from juvenile-onset diabetics and healthy con-

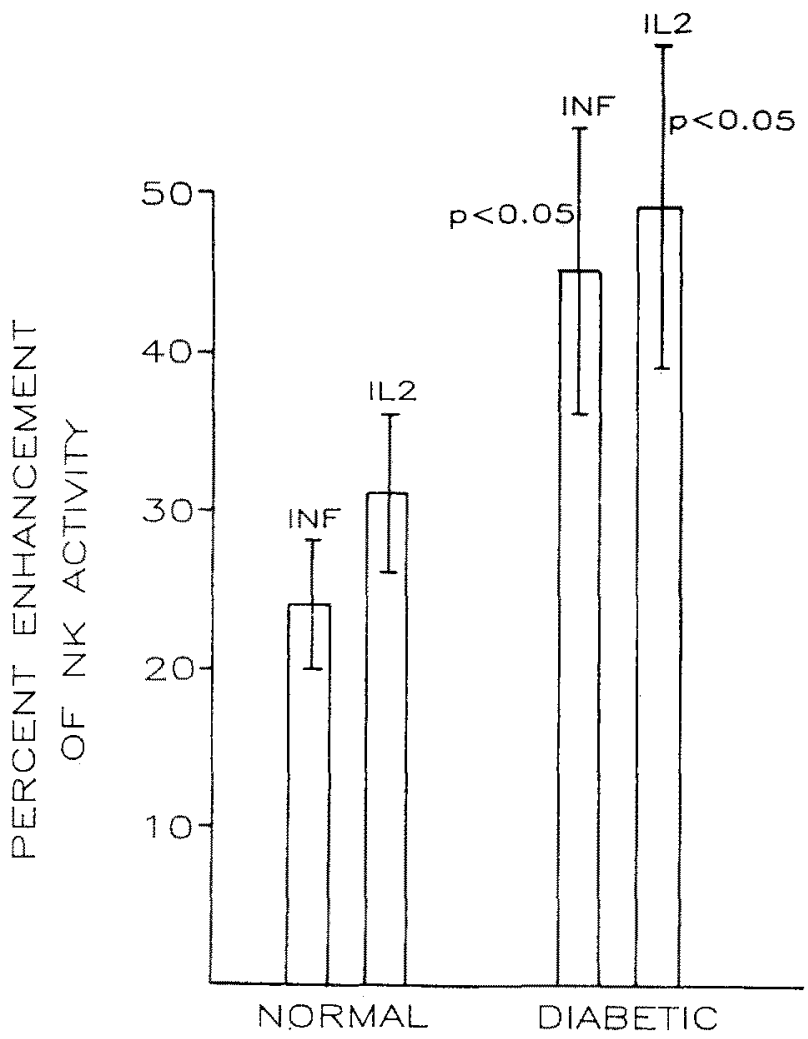

Fig. 2. Effect of interferon and interleukin-2 on the NK activity of lymphocytes from diabetics and normals. PBL depleted of adherent cells were precultured for $24 \mathrm{hr}$ with $250 \mathrm{U}$ of IFN or $64 \mathrm{U} / \mathrm{ml}$ of IL2, previously found to yield the maximum NK augmenting effect. Washed PBL were tested for NK activity against prelabeled K562 target cells at a 50:1 E:T cell ratio. Enhancement of NK activity by IFN or IL2 treatment of lymphocytes was calculated in comparison with untreated control lymphocytes. The statistical significance of differences was determined using a single-tail Student $t$ test. trols. It was also shown that insulin augments the metabolism of activated $\mathrm{T}$ cells in a rat model (30). The results reported herein demonstrate that insulin may have some stimulatory effect on the cytotoxic activity of precultured normal lymphocytes (Table III). Enhancement of cytotoxicity by exogenous insulin may partially explain the paradoxical observation of normal NK function by IDDM lymphocytes in spite of decreased Leu 7- and T8-positive lymphocytes as reported by others $(23,24,26,31)$. Since $\mathrm{T}$ lymphocytes can also express NK-like cytotoxicity against K562 targets, this effect of insulin may be due to recruitment of functionally NK reactive cells from the $T$-cell population. Experiments using purified $\mathrm{HNK} 1^{+}$or Leu $7^{+}$mono-

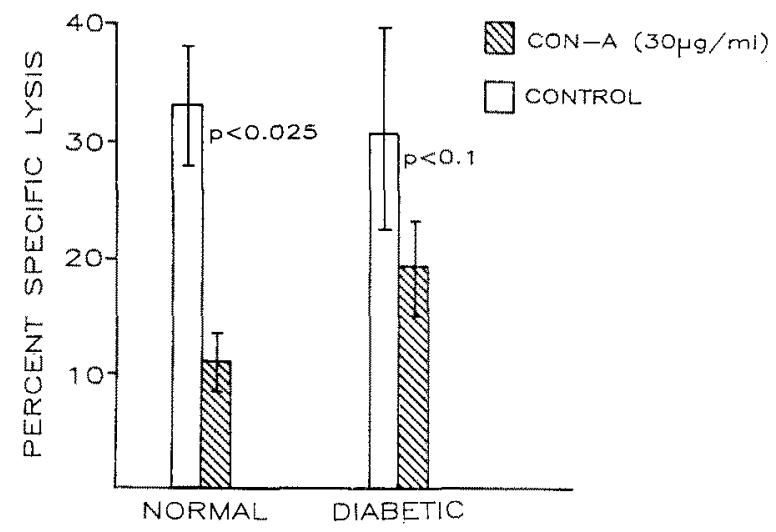

Fig. 3. NK activity of Con A-activated lymphocytes. Total mononuclear cells from both control and IDDM patients were cultured with and without $30 \mu \mathrm{g}$ Con $\mathrm{A} / \mathrm{ml}$ for $48 \mathrm{hr}$. Values represent the mean cytotoxicity $\pm S D$ of four separate experiments, with triplicate determinations for each at an E:T cell ratio of $50: 1$. The statistical significance of differences was calculated using a singletail Student $t$ test. 
Table IV. Suppression of NK Activity of Normal Lymphocytes by Lymphocytes Precultured with Con $\mathrm{A}^{a}$

\begin{tabular}{lc}
\hline $\begin{array}{l}\text { Source of Con A- } \\
\text { treated PBL }\end{array}$ & $\begin{array}{c}\% \\
\text { suppression }\end{array}$ \\
\hline Normals & \\
1 & $57.2^{c}$ \\
2 & 22.4 \\
3 & 25.7 \\
4 & 48.2 \\
5 & 37.1 \\
& $38.1 \pm 14.7$ \\
Diabetics & \\
1 & 13.7 \\
2 & 3.5 \\
3 & 48.1 \\
4 & 1.4 \\
5 & 18.3 \\
& $17.0 \pm 18.7$ \\
& $(P<0.25)$ \\
Prediabetics & \\
1 & 63.8 \\
2 & 46.6 \\
& $55.2 \pm 12.1$ \\
& $(P<0.25)$
\end{tabular}

"In mixing experiments to measure suppressor-cell activity, PBL precultured with or without Con A were added separately to a mixture of effector and ${ }^{51} \mathrm{Cr}$-labeled K562 target cells.

${ }^{b}$ Suppression was calculated as described in Materials and Methods.

Values represent the mean percentage suppression of triplicate determinations of each sample.

${ }^{d}$ Islet-cell antibody-positive patients without overt disease.

nuclear cells and isolated $\mathrm{T}$ cells may resolve this issue, although $\mathrm{HNK} 1^{+}$cells represent only a small proportion of NK cells. IFN and IL2 seem to have a major role in immunoregulation $(32,33)$ and in augmentation of $\mathrm{NK}$ activity both in vitro and in vivo $(33,34)$. IFN may enhance NK activity by several mechanisms including stimulation of noncytotoxic pre-NK cells to mature cytotoxic effector cells (35) and activation of mature NK cells that are transiently inactive (36). Alternatively, IFN may potentiate endogenous lytic mechanisms by inducing the development of new receptors or modulating preexisting effector-cell surface receptors or their avidity (35-37). It has also been shown that IL2 can induce IFN; this has been used successfully in the establishment of NK clones (37). Recently Svedersky et al. (39) reported that augmentation of NK activity by IL2 and IFN involves overlapping mechanisms. Hayward and Herbenger (40) demonstrated that lymphocytes from IDDM patients had increased numbers of IL2 receptor-positive cells. Chandy et al. (41) showed that exogenous IL2 reversed the AMLC reaction in diabetics, whereas
Zier et al. (42) demonstrated decreased synthesis of IL2 by diabetic lymphocytes. Consistent with these observations our data further demonstrate that lymphocytes from patients with IDDM show increased enhancement of cytotoxicity when stimulated with IL2 and IFN, in contrast to PBL from healthy donors. Thus although lymphocytes from IDDM patients may produce less IL2 than control cells, they may be more responsive to lower endogenous levels of IL2, possibly through the greater proportion of circulating IL2 receptor-bearing cells as compared with healthy controls. We have earlier reported that unstimulated cultured normal human lymphocytes can develop suppressor-cell activities against NK and ADCC reactions as a possible consequence of an AMLC (17). This suppressorcell activity could be further enhanced by preculturing lymphocytes with Con A. Previous studies have shown that IDDM patients demonstrate reduced antigen-specific or nonspecific suppressor-cell activities in vitro as measured by the lymphocyte proliferative response to mitogen and alloantigens (43-45). Although preculture of lymphocytes from IDDM patients or controls with Con A results in diminished NK activity, treated PBL from diabetics demonstrated persistently higher NK activity than controls. This observation is consistent with the premise that Con $A$ was not as effective in inducing suppressor activity in PBL from IDDM patients as it was with normal lymphocytes. To confirm this, mixing experiments utilizing Con A-pretreated lymphocytes were undertaken. Our results indeed demonstrated a deficiency of Con A-inducible suppressor cells using lymphocytes from IDDM patients. Because of the increasing evidence that cytotoxic cells may be involved in the destruction of pancreatic beta cells, an analysis of the interplay between activated suppressor cells and NK cells may further elucidate the immunopathogenesis of IDDM.

Diminished suppressor-cell functions associated with IDDM may explain, in part, the escape of cytotoxic activities from normal immunoregulatory mechanisms resulting in islet-cell destruction. The paradoxical observation of increased NK activity associated with the prediabetic state may be a manifestation of normal immunologic antiviral surveillance, especially if one considers a possible viral etiology for IDDM. Thus suppressor-cell activation might counteract progressive destruction of uninfected islet cells after elimination of any putative initial infection. Failure of suppressor-cell activation could ultimately result in total islet-cell 
destruction and IDDM. Moreover, cytotoxicity may be further stimulated by an increased sensitivity to IFN and IL2 as our data suggest.

The studies reported herein using tumor-cell targets are our initial investigations examining cytotoxic activities in IDDM. Further experiments using pancreatic islet-cell targets will attempt to address the specificity of these observations. In summary, however, it appears that IDDM may be associated with an increased sensitivity of cytotoxic cells to enhancement with IFN and IL2 and decreased suppressor-cell activity. These immunologic mechanisms may play a role in the pathogenesis of the disease.

\section{ACKNOWLEDGMENTS}

We express our sincere appreciation to Jean Cilik for her technical assistance and Denise DuPrie for her excellent secretarial assistance.

This research was aided by the National Institutes of Health (Grants CA35922 and AI 19890) and the Children's Leukemia Foundation of Michigan and a Pilot Feasibility Grant (\#2P60 AM20572) from the Michigan Diabetes Research and Training Center, The University of Michigan.

Dr. Schwartz is the recipient of Research Career Development Award \#00896 from the National Cancer Institute.

\section{REFERENCES}

1. Gepts W: Pathologic anatomy of the pancreas in juvenile diabetes mellitus. Diabetes 14:619-633, 1965

2. Bottazzo GF, Florin-Christensen A, Doniach D: Islet-cell antibodies in diabetes mellitus with autoimmune polyendocrine deficiencies. Lancet 2:1279-1281, 1974

3. Rittenhouse HG, Oxender DL, Pek S, Ar D: Complement mediated cytotoxic effects in pancreatic islets with sera from diabetic patients. Diabetes 29:317-322, 1980

4. Yoon JW, Austin M, Onodera T, Notkins AL: Virus induced diabetes mellitus in man. N Engl J Med 300:1173-1179, 1979

5. Alviggi L, Johnston C, Hoskins PJ, Tee DE, Pyke DA, Leslie LD, Vergani D: Pathogenesis of insulin-dependent diabetes. A role for activated T lymphocytes. Lancet 2:4-6, 1984

6. Sensi M, Pozzill P, Gorsuch AN, Bottazo GF, Cudworth AG: Increased killer cell activity in insulin dependent (Type I) diabetes mellitus. Diabetologia 20:106-109, 1981

7. Huang SW, MacLaren NK: Insulin-dependent diabetes: A disease of autoaggression. Science 192:64-66, 1976

8. Nerup J, Anderson OO, Bendixen G, Egeberg J, Gunnarsson R, Kromann H, Paulsen JE: Cell mediated immunity in diabetes mellitus, Proc R Soc Med 67:506-513, 1974
9. MacCuish AC, Jordan J, Campbell CJ, Duncan LPJ, Irvine WJ: Cell mediated immunity in diabetes mellitus. Lymphocyte transformation by insulin and insulin fragments in insulin treated and newly diagnosed diabetics. Diabetes $24: 36-43,1975$

10. Herberman RB: NK and Other Natural Effector Cells. New York, Academic Press, 1980

11. Cudkowicz G, Hochman PS: Do natural killer cells engage in regulated reactions against self to ensure homeostasis? Immunol Rev 44:13, 1979

12. Nair MPN, Fernandes G, Onoe K, Day NK, Good RA: Inhibition of effector cell functions in natural killer cell activity (NK) and antibody-dependent cellular cytotoxicity (ADCC) in mice by normal and cancer sera. Int $J$ Cancer 25:667-677, 1980

13. Boyum A: Isolation of mononuclear cells and granulocytes from human blood. Isolation of mononuclear cells by one centrifugation and of granulocytes by combining centrifugation and sedimentation. J Clin Lab Invest 21 (Suppl 97):77, 1968

14. Nair MPN, Schwartz SA: Effect of histamine and histamine antagonists on natural and antibody dependent cellular cytotoxicity of human lymphocytes in vitro. Cell Immunol $81: 45-60,1983$

15. Kadish AS, Doyle AT, Steinhaner EH, Ghossein NA: Natural cytotoxicity and interferon production in human cancer: deficient natural killer activity and normal interferon production in patients with advanced disease. J Immunol 127:1817-1822, 1981

16. Nair MPN, Schwartz SA, Menon M: Association of decreased natural and antibody-dependent cellular cytotoxicity and production of natural killer cytotoxic factor and interferon in neonates. Cell Immunol 94:159-171, 1985

17. Nair MPN, Schwartz SA: Suppression of natural killer activity and antibody dependent cellular cytotoxicity by cultured human lymphocytes. J Immunol 126:2221-2229, 1981

18. Pozzilli P, Zuccarini O, Tavicoli M, Andreeni D, Sensi M, Spencer KM, Bottazzo GF, Beverley PCL, Kyner JL, Cudworth AG: Monoclonal antibodies defined abnormalities of $\mathrm{T}$ lymphocytes in type I (insulin-dependent) diabetes. Diabetes 32:91-94, 1983

19. Jackson RA, Morris MA, Haynes GV, Eisenbach GS: Increased circulating Ia antigen bearing $\mathrm{T}$ cells in type $\mathrm{I}$ diabetes mellitus. N Engl J Med 306:785-788, 1982

20. Horila M, Suzuki H, Onodera T, Ginsberg-Fellner F, Fauci AS, Notkins AL: Abnormalities of immunoregulatory $\mathrm{T}$ cell subsets in patients with insulin-dependent diabetes mellitus. J Immunol 129:1425-1429, 1982

21. Pozzilli P, Sensi M, Gorsuch A, Bottazzo GF, Cudworth $A G$ : Evidence for raised $K$ cell levels in type I diabetes. Lancet 2:173-175, 1979

22. Charles A, Suzuki M, Waldeck N, Dodson LE, Slater L, Ong K, Kershnar A, Buckingham B, Golden M: Immune islet killing mechanisms associated with insulin dependent diabetes. In vitro expression of cellular and antibody mediated islet cell cytotoxicity in humans. $J$ Immunol 130:1189-1194, 1983

23. Harold KC, Huen A, Gould L, Traisman H, Rubenstein AH: Alterations in lymphocyte subpopulations in type I (insulindependent) diabetes mellitus. Exploration of possible mech- 
anisms and relationships to autoimmune phenomena. Diabetologia 27 (Suppl): 102-105, 1984

24. Chandy KG, Charles MA, Ruckingham B, Waldeck N, Kershnar A, Gupta S: Deficiency of monoclonal antibody (Leu 7) defined NK cells in newly diagnosed insulin dependent diabetes mellitus. Immunol Lett 8:89-91, 1984

25. Kohler E, Kuospe S, Woltanski G, Maciejewski R, Salzsieder C, Rjasanowski I, Stress J, Michaelis D: Antibody dependent cell mediated cytotoxicity of mononuclear cells against Langerhans islets of Wistar rats in normal man and in patients at diabetic risk. Biomed-Biochem Acta $43(5): 627-633,1984$

26. Galluzzo A, Giordano C, Rubin G, Bompiani GD: Immunoregulatory $\mathrm{T}$-lymphocyte subset deficiency in newly diagnosed Type I (insulin dependent) diabetes mellitus. Diabetologia 26:426-430, 1984

27. Brunda M, Varesio L, Herberman RB, Holden HT: Interferon independent, lectin-induced augmentation of murine natural killer cell activity. Int J Cancer 29:299, 1982

28. Spits H, Borst J, Terhorst C, DeVris JE; The role of T cell differentiation markers in antigen-specific and lectin dependent cellular cytotoxicity mediated by $\mathrm{T}^{+}$and $\mathrm{T}^{+}$human cytotoxic $\mathrm{T}$ cell clones directed at class I and class II MHC antigens. J Immunol 129:1563, 1982

29. Helderman H, Raskin P: The T lymphocyte insulin receptor in diabetes and obesity. An intrinsic binding defect. Diabetes 29:551-557, 1980

30. Helderman $\mathbf{J H}$, Edwards L: Role of insulin in the intermediary metabolism of activated thymic-derived lymphocytes. $\mathrm{J}$ Clin Invest 67:1636-1642, 1981

31. Quinou-Debrie MC, Debray-Sachs M, Dardenne M, Czernichow P, Assan R, Bach JF: Anti-islet cellular and humoral immunity, $T$ cell subsets, and thymic function in type I diabetes. Diabetes 34:373-379, 1985

32. Bishop GA, Schwartz SA: Enhancement of human natural killer cells by interferon requires DNA and protein synthesis. Clin Immunol Immunopathol 25:374-385, 1982

33. Herberman RR, Ortaldo JR, Bonnard GD: Augmentation by interferon of human natural and antibody-dependent cellmediated cytotoxicity. Nature 277:221-223, 1979
34. Lattim EC, Pecoraro GA, Stutman O: The activity of natural cytotoxic cells is augmented by interleukin 2 and interleukin 3. J Exp Med 157:1070-1075, 1983

35. Saksela E, Timonen T, Cantell K: Human natural killer cell activity is augmented by interferon via recruitment of "preNK" cells. Scand J Immunol 10:257, 1979

36. Perussia B, Trinchieri $G$ : Inactivation of natural killer cell cytotoxic activity after interaction with target cells. J Immunol 126:754-758, 1981

37. Ortaldo JR, Pestka S, Slease RB, Rubinstein MI, Herberman RB: Augmentation of human NK-cell activity with interferon. Scand J Immunol 12:365-369, 1980

38. Pearlstein KT, Palladino MA, Welte K, Vifcek J: Purified human interleukin 2 enhances induction of immune interferon. Cell Immunol 80:1-9, 1983

39. Svedersky LP, Shepard HM, Spencer SA, Shalaby MR, Palladino MA: Augmentation of human natural cell-mediated cytotoxicity by recombinant human interleukin 2 . J Immunol 133:714-718, 1984

40. Hayward AR, Herberger M: Phenotype of activated T-cells from patients with type I diabetes mellitus. Diabetes 33(4):319-323, 1984

41. Chandy KG, Charles AM, Kershnar A, Buckingham B, Waldeck N, Gupta S: Autologous mixed lymphocyte reaction in man. XV. Cellular and molecular basis of deficient autologous mixed lymphocyte response in insulin-dependent diabetes mellitus. J Clin Immunol 4:424-428, 1984

42. Zier KS, Leo MM, Spielman RS, Baker L: Decreased synthesis of interleukin 2 (IL2) in insulin dependent diabetes mellitus. Diabetes 33(6):552-555, 1984

43. Horowitz SD, Borcherding W, Bargman GJ: Suppressor T cell function in diabetes mellitus. Lancet $2: 1291,1977$

44. Buschard K, Madsbad S, Rygaard J: Depressed suppressor cell activity in patients with newly diagnosed insulin-dependent diabetes mellitus. Clin Exp Immunol 41:25-32, 1980

45. Fairchild RS, Kyner JL, Abdou NI: Specific immunoregulation abnormality in insulin dependent diabetes mellitus. $\mathrm{J}$ Lab Clin Med 99:175-185, 1982 